\author{
G.K. Tleuzhanova ${ }^{1}$, O.A. Andreyeva ${ }^{2, *}$, Zh.K. Akhmadieva ${ }^{3}$ \\ ${ }^{1,2}$ Karagandy University of the name of academician E.A. Buketov, Kazakhstan; \\ ${ }^{3}$ International University of Astana, Kazakhstan \\ (E-mail:post1976@mail.ru) \\ ORCID ID: https://orcid.org/0000-0003-2302-1595 \\ ORCID ID: https://orcid.org/0000-0002-4147-4697
}

\title{
Interdisciplinary integration as a pedagogical condition for preparing students for professional activities
}

\begin{abstract}
The strategic objectives of trilingual education in Kazakhstan have actualized the need to prepare students of pedagogical specialties to use English in their professional activities in the context of modernization of education in the Republic of Kazakhstan. On the basis of the research carried out, the authors of the article present their vision of the success of this process, which, in their opinion, lies in the careful selection of pedagogical conditions, one of which is interdisciplinary integration, as a tool that contributes to the integrated educational and methodological support of the process of teaching professionally oriented English with taking into account the specifics of the specialty. A consistent transition between disciplines will contribute to the formation of a consistency of knowledge based on the development of general scientific ideas and concepts, the improvement of professionally oriented knowledge and skills of students, coordination in the work of teachers of various disciplines, their cooperation, a unified interpretation of general scientific concepts, consistency in the implementation of complex forms of organizing the educational process, integrated educational and methodological support of the process of teaching professionally oriented English, taking into account the specifics of the specialty.
\end{abstract}

Keywords: pedagogical conditions, interdisciplinary integration, trilingual education, professional activity, readiness, pedagogical specialties, language training, professionally oriented English.

\section{Introduction}

In the context of the modernization of education in the Republic of Kazakhstan, higher education is faced with the task of creating a qualitatively new system for training future specialists. At the stage of the formation of a new paradigm of education, it is of fundamental importance to find ways to form the readiness of students of pedagogical specialties to use English in their professional activities. The success of this process, in our opinion, will depend on carefully selected pedagogical conditions.

On the basis of scientific psychological and pedagogical research, it can be determined that scientists correlate the concept of «condition» with such concepts as «circumstance», «set of circumstances», «measure», «opportunities», «requirements», on which the success of the educational process depends.

So, I.P. Podlasy, considering the conditions of the pedagogical process, distinguishes external conditions: natural-geographical, social, industrial, cultural and internal: material and technical, sanitary and hygienic, moral and psychological, etc. [1].

A.F. Amend by pedagogical conditions is understood as a set of measures of the educational process that provide the necessary level of development of the desired category of the student's personality [2].

L.B. Trubaichuk also determines the pedagogical condition in the educational process as the circumstances that contribute to the achievement or, on the contrary, inhibit them[3].

A.C. Belkin, E.V. Tkachenko represent pedagogical conditions as generalized requirements for the nature of the organization of the educational process, implying the creation of a virtual educational environment with such properties that would allow to model the process of acquiring vitagenic experience by a person in the process of life [4;242].

Summarizing the above provisions in scientific literature and pedagogical research, we can conclude that the concept of «pedagogical conditions» as a whole is considered as a set of circumstances aimed at achieving a specific goal of the activity being carried out.

\footnotetext{
*Corresponding author's e-mail: post1976@mail.ru
} 


\section{Materials and Methods}

Taking into account the definitions given above, and based on the definition of A. Ya. Najn [5; 16]: «Pedagogical conditions are a set of objective possibilities, content, forms, methods and material-spatial environment aimed at solving the assigned tasks», we understand the pedagogical conditions that contribute to the formation of the readiness of students of pedagogical specialties to use the English language in professional activities, as a set objective possibilities of content, forms, methods, techniques of professional training, material and spatial environment, aimed at the formation of readiness to use the English language in professional activities in the unity of motives, knowledge and skills.

Many dissertations are devoted to the problem of the conditions for the formation of readiness for various aspects of professional activity, as well as the problem of the formation of readiness to use a foreign language in pedagogy, which is of greatest interest within the framework of this research. So, I.S. Radchenko identifies the following conditions for the formation of readiness:

- creation of a model for the formation of readiness;

- creation of a comfortable educational environment, the formation of positive emotions, modeling by the teacher of the situation of success in the learning process;

- the teacher's readiness to manage the educational and professional activities of students in the learning process;

- availability of methodological support for the process under study [6].

M.V. Kislinskaya, exploring the process of formation of a foreign language culture, defines the following pedagogical conditions:

- ensuring compliance of the content of foreign language education with the level of professional aspirations of students;

- the formation of motivation, providing the subject-subject value character of students' attitudes to a foreign language culture;

- formation of foreign language readiness in terms of professional communication;

- reliance on native culture [7].

T.N. Galinskaya, B.L. Temkina under the pedagogical conditions for the development of readiness for professional communication understand as a set of measures aimed at increasing the efficiency of the process of developing communicative readiness in the professional sphere. This understanding of the essence and characteristics of the definition of the concept of pedagogical conditions help the authors highlight the most significant conditions for the development of the readiness of students of pedagogical specialties to use English in their professional activities:

- ensuring communicative impact on the intellectual, motivational, value and behavioral spheres of the individual;

- organization of gradual teaching of university students to communicate in dialogical forms of interaction between teachers and students;

- modeling of real situations of foreign language communication based on the activity approach [8].

S.V. Motorina [9] identifies the following pedagogical conditions in the formation of foreign language readiness for professional activity among students of humanitarian specialties:

1) holistic immersion of students in professionally oriented activities and the formation of sustainable motivation for learning a foreign language;

2) ensuring interdisciplinary connections and continuity at all stages of teaching students a foreign language;

3) intensification of learning through the use of innovative pedagogical technologies in the educational process at the university.

Thus, it is clear that the authors of dissertation research distinguish different sets of pedagogical conditions. Such a variety of conditions is explained by differences in the setting of research goals, requirements for the quality of training, theoretical and methodological approaches to the study of the problem, etc. But in general, it can be argued that these pedagogical conditions in scientific works are based on general philosophical, psychological and pedagogical provisions as the basis for research and have common features, which is explained by the presence of similar research objects.

Determining the totality of pedagogical conditions contributing to the formation of the readiness of students of pedagogical specialties to use the English language in their professional activities, we took into account the following: 1) professional requirements imposed by society on a modern specialist; 2) features of 
professional communication in preparation for professional activity of students of pedagogical specialties; 3 ) the leading ideas of the integrative-activity approach, elements of the modular approach, interdisciplinary integration; 4) the results of the ascertaining stage of the experiment.

The essence of the structure of the concept of readiness to use the English language in professional activity, which we consider as an integrative personal education, which includes knowledge and skills, positive motivation necessary for the successful implementation of a certain type of professional activity and understanding of the essence and characteristics of the definition of the concept of «pedagogical conditions» leads us to the need to highlight such pedagogical conditions that should ensure the formation and development of students' readiness to use English in professional activity in the unity of the cognitive, praxeological and motivational components of the above readiness.

The cognitive component of the readiness of students of pedagogical specialties to use the English language in their professional activities includes a set of theoretical knowledge for the implementation of professionally oriented communication in English, namely: linguistic, sociolinguistic and professional communicative knowledge.

This characteristic of the complex of knowledge proceeds from the specifics of the study of the English language by students of pedagogical specialties, where all training should reflect the characteristics of the disciplines and professions that it serves, therefore, all educational activities, content and teaching methods are close to the needs of future professional activities. Such work, aimed at mastering basic communicative knowledge, is carried out in the process of forming students' readiness to teach in English using professionally oriented texts based on the material of the disciplines of general professional training and the discipline «Professionally oriented foreign language».

Thus, one of the necessary conditions ensuring the formation of the readiness of students of pedagogical specialties to use the English language in their professional activities is to provide students with a complex of linguistic, sociolinguistic, professional and communicative knowledge through the integration of various forms of teaching and interdisciplinary integration.

Currently, foreign experts are conducting research in the field of language training as one of the means of studying non-linguistic disciplines. We studied the experience of some countries in this area. Thus, in Europe, the Middle East, Southeast Asia and Japan, the CLIL (Content and Language Integrated Learning) approach has become widespread [10; 389]. In North America, it was named CBI (Content Based Instruction). According to these approaches, one of the conditions for language training is parallel teaching of specialized disciplines in English [11; 70]. Such approaches not only carry sociocultural value, but also suggest using English as an additional tool to gain advantages in a competitive world [12;488].

Also, this idea was embodied in the works of N.E. Astafyeva, Yu.K.Babansky, V.P. Bespalko, E.D. Erzhanova, L.K. Karabaeva, V.V. Kraevsky, N.I. Reznik, A.A. Sarsembaeva, G.M. Strizhkova, L.L. Yurova, L.V. Filatyeva and etc.

\section{Results and Discussion}

In the process of developing readiness to use English in professional activities, it is necessary to highlight interdisciplinary connections, i.e. mutual coherence of curricula, due to the system of sciences and didactic goals. The didactic principles of scientific character, systematicity and continuity of knowledge require the arrangement of individual academic disciplines in the curriculum in such a way that the study of one can rely on the knowledge presented in other disciplines [13]. This provision is important when teaching a professionally oriented foreign language.

In order to study the issue of interdisciplinary integration, we analyzed the working curricula of specialties 5B011200 - Informatics, 5B011200 - Chemistry, 5B011300 - Biology, 5B011400 - Physics for 4 years of study, namely 2016-2019 years of admission. The task of studying this issue was to determine the position of language and special disciplines, including those taught in English, in the working curricula of the above specialties.

This analysis showed that in all four specialties the discipline «Professionally oriented foreign language» was studied in the 6th semester, when special disciplines and special disciplines in English - in 2-5 semesters. Since 2019, the discipline «Professionally oriented foreign language» has not been included in the working curricula of specialties «Biology», «Physics».

This situation in relation to the study of the discipline «Professionally oriented foreign language», in our opinion, cannot but affect the level of professional training using the English language of the abovementioned specialties. The present arrangement of linguistic and special disciplines does not correspond to 
the implementation of the principle of systematicity and continuity, which is organically linked to the principle of scientific character, which implies a consistent arrangement of educational material in the working curriculum, reliance on previous knowledge, consistency between them, taking into account interdisciplinary integration.

We conducted a survey of teachers teaching special disciplines in English at the faculties of mathematics and information technology, chemical, biological-geographical, physical and technical E.A. Buketov Karaganda University. 36 teachers took part in the survey. First of all, teachers were asked to assess the language preparation of students for the beginning of the study of special disciplines in English. $82 \%$ of teachers defined the level of students as low / elementary proficiency (they can read and translate using a dictionary), $18 \%$ as an average / independent proficiency (know how to read and translate texts using a dictionary, verbally and in writing to express their thoughts and opinions, using simple grammatical constructions and vocabulary) and none of the teachers noted the high (fluency) level of students' language training.

As the reasons for the above indicators of the language training of students before the beginning of the study of special disciplines in English, teachers indicate: poor language training of graduates of secondary schools (70 \%), low motivation of students to learn English (20\%), insufficient level of provision of the process of teaching English appropriate level educational and methodical literature and technical equipment $(10 \%)$.

As measures to improve the language training of students before starting to study special disciplines in English, $80 \%$ of teachers point to the need to ensure continuity between the discipline «Professionally oriented foreign language» and special disciplines.

\section{Conclusions}

The results of the study confirm the necessity and expediency of the use of interdisciplinary integration in the process of forming the readiness of students of pedagogical specialties to use English in their professional activities. A gradual transition between disciplines will contribute to the formation of a consistency of knowledge based on the development of general scientific ideas and concepts, the improvement of professionally oriented knowledge and skills of students, coordination in the work of teachers of various disciplines, their cooperation, a unified interpretation of general scientific concepts, consistency in the implementation of complex forms of organizing the educational process, integrated educational and methodological support of the process of teaching professionally oriented English, taking into account the specifics of the specialty.

Taking into account the above, as the first pedagogical condition that contributes to the formation of the cognitive component of the readiness of students of pedagogical specialties to use English in their professional activities, we single out the provision of students with a set of knowledge necessary for the use of English in professional activities based on interdisciplinary integration.

\section{References}

1 Подласый И.П. Педагогика: учеб. пос. для студ. высш. учеб. зав. / И.П. Подласый. — М.: Просвещение; ВЛАДОС, 1996. - 432 с.

2 Аменд А.Ф. Теория и практика непрерывного эколого-экономического образования: моногр. / А.Ф. Аменд. - Челябинск: Изд-во «Факел», 1996. - 152 с.

3 Словарь-справочник педагогических инноваций в образовательном процессе. - М.: Изд. дом «Восток», 2001. - 81 с.

4 Белкин А.С. Диссертационный совет по педагогике (опыт, проблемы, перспективы) / А.С. Белкин. - Екатеринбург, 2005. $-208 \mathrm{c}$.

5 Найн А.Я. Вопросы систематизации категории педагогики: понятийный аппарат педагогики и образования: сб. науч. тр. - Вып. 1. - Екатеринбург, 1995. - С. 23-36.

6 Радченко И.С. Обучение технике деловой беседы студентов экономических специальностей: автореф. дис.... канд. пед. наук / И.С. Радченко. - Оренбург, 2006. - 22 с.

7 Кислинская М.В. Педагогические условия формирования культуры студентов колледжа в процессе профессиональной подготовки: автореф. дис.... канд. пед. наук / М.В. Кислинская. - Магнитогорск, 2007. - 24 с.

8 Галинская Т.Н. Особенности обучения иноязычному деловому общению в университете / Т.Н. Галинская // Вестн. ВГУ. Сер. Лингвистика и межкультурная коммуникация. - № 12. - 2005. - С. 36-40.

9 Моторина С.В. Формирование иноязычной готовности к профессиональной деятельности у студентов гуманитарных специальностей: автореф. дис.... канд. пед. наук / С.В. Моторина. - Чита, 2006. — 23 с.

10 CrossR. Languageandcontent 'integration': Theaffordancesofadditionallanguagesasatoolwithinasinglecurriculumspace. Journal of Curriculum Studies, 2016, vol. 48, no. 3, pp. 388-408. DOI: https://doi.org/10.1080/00220272.2015.1125528. 
11 Roussel S., Joulia D., Tricot A., Sweller J. Learning subject content through a foreign language should not ignore human cognitive architecture: A cognitive load theory approach. Learning and Instruction, 2017, vol. 52, pp. 69-79. DOI: http://dx.doi.org/10.1016/j.learninstruc.2017.04.007.

12 Perez A., Lorenzo F., Pavon V. European bilingual models beyond lingua franca: Key findings from CLIL French programs. Language Policy, 2016, vol. 15, issue 4, pp. 485-504. DOI: https://doi.org/10.1007/s10993-015-9386-7.

13 Крившенко Л.П. Педагогика: учеб./ Л.П. Крившенко. — М.: Проспект, 2010. — 432 с.

\title{
Г.К. Тлеужанова, О.А. Андреева, Ж.К. Ахмадиева
}

\section{Пәнаралық интеграция студенттердің ағылшын тілін кәсіби қызметте қолданудағы даярлығын қалыптастырудың педагогикалық шарты ретінде}

\begin{abstract}
Қазақстанда үштілді білім берудің стратегиялық міндеттері педагогикалық мамандықтар студенттерін Қазақстан Республикасының білім беруді жаңғырту жағдайында кәсіби қызметте ағылшын тілін қолдануға дайындау қажеттілігін өзектендірді. Жүргізілген зерттеулер негізінде мақала авторлары осы үдерістің сәттілігі туралы өз көзқарастарын ұсынған, олардың пікірінше, мамандықтың ерекшелігін ескере отырып, кәсіби-бағытталған ағылшын тілін оқыту процесін интеграцияланған оқуәдістемелік қамтамасыз етуге ықпал ететін құрал ретінде пәнаралық интеграция болып табылатын педагогикалық жағдайларды мұқият таңдаудан тұрады. Пәндер арасындағы дәйекті ауысу жалпы ғылыми идеялар мен тұжырымдамаларды дамытуға негізделген білім жүйесін қалыптастыруға, студенттердің кәсіби бағытталған білімі мен дағдыларын жетілдіруге, әртүрлі пәндер оқытушыларының жұмысын үйлестіруге, олардың ынтымақтастығына, жалпы ғылыми тұжырымдамаларды бірыңғай түсіндіруге және оку процесін ұйымдастырудың күрделі формаларын жүзеге асырудағы дәйектілікке, мамандықтың ерекшелігін ескере отырып, кәсіби-бағытталған ағылшын тілін оқыту процесін кешенді оқу-әдістемелік қамтамасыз етуге негізделген жүйелі білімді қалыптастыруға ықпал етеді.
\end{abstract}

Кілm сөздер: педагогикалық шарттар, пәнаралық интеграция, үштілді білім беру, кәсіби қызмет, дайындық, педагогикалық мамандықтар, тілдік дайындық, кәсіби-бағытталған ағылшын тілі.

\section{Г.К. Тлеужанова, О.А. Андреева, Ж.К. Ахмадиева}

\section{Междисциплинарная интеграция как педагогическое условие подготовки студентов к профессиональной деятельности}

\begin{abstract}
Стратегические задачи трехъязычного образования в Казахстане актуализировали необходимость подготовки студентов педагогических специальностей к использованию английского языка в профессиональной деятельности в условиях модернизации образования Республики Казахстан. На основе проведенных исследований авторы статьи представляют свое видение успешности данного процесса, которое заключается, по их мнению, в тщательном подборе педагогических условий, одним из которых является междисциплинарная интеграция как инструмент, способствующий интегрированному учебно-методическому обеспечению процесса обучения профессионально-ориентированному английскому языку с учетом специфики специальности. Последовательный переход между дисциплинами будет способствовать формированию системности знаний на основе развития общенаучных идей и понятий, совершенствованию профессионально направленных знаний и умений студентов, координации в работе преподавателей различных дисциплин, их сотрудничеству, единой трактовке общенаучных понятий, согласованности в проведении комплексных форм организации учебно-воспитательного процесса, интегрированному учебно-методическому обеспечению процесса обучения профессионально-ориентированному английскому языку с учетом специфики специальности.
\end{abstract}

Ключевые слова: педагогические условия, междисциплинарная интеграция, трехъязычное образование, профессиональная деятельность, готовность, педагогические специальности, языковая подготовка, профессионально-ориентированный английский язык.

\section{References}

1 Podlasyj, I.P. (1996). Pedahohika [Pedagogy].Moscow: Prosveshchenie [in Russian].

2 Amend, A.F. (1996). Teoriia i praktika nepreryvnoho ekoloho-ekonomicheskoho obrazovaniia [Theory and practice of continuous environmental and economic education]. Cheliabinsk: Fakel [in Russian]. 
3 Slovar-spravochnik pedahohicheskikh innovatsii v obrazovatelnom protsesse [Dictionary-reference book of pedagogical innovations in the educational process]. Moscow: Vostok [in Russian].

4 Belkin, A.S. (2005). Dissertatsionnyi sovet po pedahohike (opyt, problemy, perspektivy) [Dissertation Council on Pedagogy (experience, problems, prospects)]. Ekaterinburg [in Russian].

5 Najn, A.Ya. (1995). Voprosy sistematizatsii katehorii pedahohiki: poniatiinyi apparat pedahohiki i obrazovaniia: sbornik nauchnykh trudov [Questions of systematization of the category of pedagogy: the conceptual apparatus of pedagogy and education: Collection of scientific. works]. Ekaterinburg [in Russian].

6 Radchenko, I.S. (2006). Obuchenie tekhnike delovoi besedy u studentov ekonomicheskikh spetsialnostei: avtoreferat dissertatsii .... kandidata pedahohicheskikh nauk [Teaching the technique of business conversation for students of economic specialties: dis. abst .... Cand. ped. sciences]. Orenburg [in Russian].

7 Kislinskaya, M.V. (2007). Pedahohicheskie usloviia formirovaniia kultury studentov kolledzha v protsesse professionalnoi podhotovki: avtoreferat dissertatsii .... kandidata pedahohicheskikh nauk [Pedagogical conditions for the formation of the culture of college students in the process of professional training: dis. abst... Cand. ped. sciences.] Magnitogorsk [in Russian].

8 Galinskaya, T.N. (2005). Osobennosti obucheniia inoiazychnomu delovomu obshcheniiu v universitete [Features of teaching foreign language business communication at the university]. Vestnik VGU. Seria linhvistika i mezhkulturnaia kommunikatsiia, 12, 36-40 [in Russian].

9 Motorina, S.V. (2006). Formirovanie inoiazychnoi hotovnosti k professionalnoi deiatelnosti u studentov humanitarnykh spetsialnostei: avtoreferat dissertatsii ... kandidata pedahohicheskikh nauk [Formation of foreign language readiness for professional activity among students of humanitarian specialties: dis. abst....Cand. ped. sciences]. Chita [in Russian].

10 Cross, R. (2016). Language and content 'integration': The affordances of additional languages as a tool within a single curriculum space. Journal of Curriculum Studies, vol. 48, no. 3, 388-408 [in English].

11 Roussel, S., Joulia, D., Tricot, A., Sweller, J. (2017). Learning subject content through a foreign language should not ignore human cognitive architecture: A cognitive load theory approach. Learning and Instruction, vol. 52, 69-79 [in English].

12 Perez, A., Lorenzo, F., Pavon, V. (2016). European bilingual models beyond lingua franca: Key findings from CLIL French programs. Language Policy, vol. 15, 485-504 [in English].

13 Krivshenko, L.P. (Ed.). Pedahohika [Pedagogy]. Moscow: Prospekt [in Russian]. 